\title{
LIBERALISM AND THE LIVING-TREE: WOMEN, EQUALITY, AND THE CHARTER'
}

\author{
LORENNE M.G. CLARK*
}

The author discusses how Lockean philosophy promotes a "minimalist" version of liberalism, as opposed to a "maximalist" concept of the liberal state which finds support in Mill's philosophy. In the former, it is argued, there is no adequate basis to allow for the promotion of sexual equality, given that the theory is grounded in "negative" freedoms which would allow substantive discrimination among individuals in the state, and would frown upon state interference in prohibiting such activities. In the latter, however, it is argued that there is a stronger basis for the state to prohibit discriminatory activities among individuals. It is argued that, since Canada was founded on the basis of the latter position, the Charter of Rights could operate to pasitively promote equality among individuals, despite the fact that it is a document adopted by, and within the context of, a "liberal" "state. On this basis, it is argued that Charter cynicism is premature, since the Charter and liberalism could both reasonably allow for the promotion of sexual equality by the state.
L'auteur explique comment les thèses de Locke favorisent une version "minimaliste" du liberalisme contrairement au concept "maximaliste" de l'état libéral préconisé par la philosophie de Mill. Dans le premier cas, l'auteur ne trouve pas de base solide permettant de promouvoir l'égalité des sexes, vu que la théorie est fondée sur des droits et libertés "négatifs" qui donneraient lieu d une discrimination importante parmi les individus de l'Etat mais rejetteraient toute intervention ératique interdisant des activités de ce type. Dans le second cas, toutefois, l'Etat est plus fortement autorisé a proscrire les actes discriminatoires parmi les individus. On soutient que, étant donné que la fondation du Canada repose sur la deuxième position, la Charte des droits pourrait servir à la promotion positive de l'égalité parmi les individus, en dépit du fait qu'il s'agit d'un document adopté par un état "libéral" et dans le contexte d'un tel état. C'est pourquoi, selon l'auteur, tout cynisme envers la Charte est prématuré, la Charte et le liberalisme autorisant tous deux, de façon raisonnable, que l'Etat encourage l'égalité entre les sexes.

\section{TABLE OF CONTENTS}

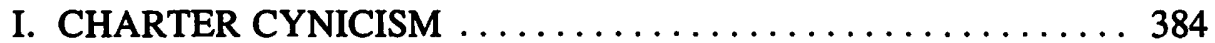

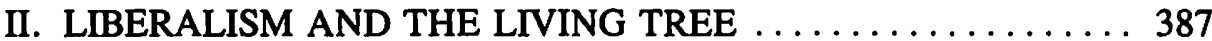

III. WOMEN'S INEQUALITY: "RELIC OF THE PAST" $\ldots \ldots \ldots \ldots 39$ IV. THE CHARTER: TOWARDS A PRINCIPLE OF "PERFECT EQUALITY"'

\section{CHARTER CYNICISM}

As is well known, ${ }^{2}$ at the time the Canadian Charter of Rights and Freedoms was being debated, Canadian women had to fight long and vigorously to ensure that the Charter included specific provisions guaranteeing equality to women. They won. Sex was included as a prohibited ground of discrimination under s. 15(1). In addition, s.28, which specifically provides that all the rights and freedoms enumerated in the Charter are guaranteed equally to male and female persons notwithstanding anything else in the Charter, was exempted from the scope of the s.33

* Executive Director of Dalhousie Legal Aid Service, and Associate Professor of Law, Dalhousie University.

1. First delivered as the Lansdowne Lecture at the Faculty of Law, University of Victoria, January 26, 1989 and subsequently delivered in the "Special Section on Rights \& Political Order" held as part of the Canadian Political Science Association Meetings at the 61st Annual Meeting of the Leamed Societies, "Section VII, Who Needs Rights? (I) Feminism", June 2, 1989, University of Laval, Quebec City, P.Q.

2. C. Hosek, "How Canadian Women Fought for Equality", (1983) 6 Canadian Forum 6ff. 
override which permits the federal government and any of the provinces to pass legislation which is, or could be, unconstitutional under s.15.

It is scarcely surprising that women were buoyed up by the victory, though many were deeply shocked and distressed by the fact that they had to mount such a pressing and persistent lobby in order to get what many assumed should simply have been included as a matter of course. Consequently, it is not surprising that women viewed the Charter with optimism and looked to it to provide an important tool in our progress toward equality. This is not to say that they were naive. Many were pessimistic about what the Charter would actually do for anyone, particularly in relation to redressing past injustices which have resulted in making some groups socially and economically disadvantaged relative to others, and women certainly fall into that category.

Women, particularly those directly involved in the struggle for the inclusion of guarantees of sexual equality, were well aware that the battle was far from over. Whether or not the Charter guarantees of sexual equality will be significant in rectifying, and hopefully, ultimately eliminating female inequality is an empirical question. But I believe that at least some of the reasons advanced in support of the position that it is unrealistic, and possibly even counter-productive, to expect much help from the Charter in the struggle for sexual equality deserve to be challenged.

The best critical assessments of the Charter's ability to assist in bringing about any fundamental change in Canadian society are those grounded in a critique of liberalism and its inherent commitment to maintaining the basic socioeconomic status quo, despite its rhetoric of freedom and justice for all. This critique, based as it is on liberal ideology, is not uniquely, or even primarily, aimed at challenging the effectiveness of a Charter to bring about any real change in the relative positions of men and women. However, it holds as little hope that it will do much to rectify the disadvantaged position of women as that it will rectify the disadvantages of any other groups relative to the dominant advantaged groups in Canadian society.

The argument is eloquently stated by Andrew Petter as follows: ${ }^{3}$

My purpose in this short essay is to put forward an argument that does not enjoy a great deal of currency on the "Charter circuit" these days. . . . The argument is that, while sold to the public as part of a "people's package", the Canadian Charter of Rights and Freedoms is a regressive instrument more likely to undermine than to advance the interests of socially and economically disadvantaged Canadians.

He begins from the premise that the Charter "is, at most, a 19th century liberal document set loose on a 20th century welfare state"4 and that the reasons why it is more likely to be regressive rather than progressive are twofold: ${ }^{5}$

The reasons for this lie partly in the nature of the rights themselves and partly in the nature of the judicial system which is charged with their interpretation and enforcement.

The criticism of the nature of the rights themselves rests on his view, first, that the rights in question are "negative" rather than "positive" in nature. These rights create privileges or negative liberties in that they merely mandate the striking down of state-sponsored restraints or impediments imposed upon individuals, thereby leaving individuals "free from" interference in particular respects. They do not,

3. A. Petter, "Immaculate Deception: The Charter's Hidden Agenda", (1987) 45 The Advocate 857.

4. Ibid.

5. Ibid. 
however, create "positive" or actual entitlements to anything, as for example, jobs, housing, or social services.

His second criticism surrounding rights is not, strictly speaking, an argument about the nature of the rights themselves so much as it is about the context in which the rights are imbedded, and this has two aspects. About the first, he says: ${ }^{6}$

The rights in the Chaner are founded upon the belief that the main enemies of freedom are not disparities in wealth nor concentrations of private power, but the state.

And the second is summed up by the following two assertions: ${ }^{7}$

The presumption underlying the Charter is that existing distributions of wealth and power are products of private initiative as opposed to state action. . . . [and] common law rules goveming the property entitlements of private parties are seen as prepolitical noms not subject to Charter scrutiny.

The net effect of this set of criticisms is summed up as follows: ${ }^{8}$

The negative nature of Charter rights combined with this selective view of state action remove from Charter scrutiny the major source of inequality in our society - the unequal distribution of property entitlements among private parties.

His second major criticism of the Charter, traceable, as he sees it, to the nature of the judicial system, is well summed up as follows: ${ }^{9}$

The victories that have been won in this century on behalf of workers, the unemployed, women and other socially and economically disadvantaged Canadians are victories that have been achieved, for the most part, in the democratic arena. . . . The point is simply that where there has been progress, with few exceptions it has come in the democratic rather than the judicial arena.

This also has two aspects: ${ }^{10}$

The first is the cost of gaining access to the system; the second is the composition of the judiciary itself.

I agree with much of what Petter and others making the same kind of points have to say on this issue. "I was a critic of liberalism when the Charter was no more than a glimmer in Pierre Trudeau's eye. I was critical of it both in relation to its ability to provide the theoretical foundations for a political, social, and legal theory guaranteeing sexual equality and its ability to supply any practical assistance in dealing with some issues of central concern to women, pornography and intrafamilial violence against women and children, to name but two of the more major ones. ${ }^{12}$ But what distresses me about current critiques of liberalism in the context of the Charter is their implication that the inequality and inferior status of women is a function specifically of liberal ideology and practice, and that the entrenching of a Charter with an admittedly liberal heritage within the Canadian welfare state must necessarily act as a brake on the evolution of Canadian social democracy. It seems to me that there is at least as much reason to assume that the impact of the social-

6. Ibid.
7. Ibid.
8. Ibid.
9. Ibid.
10. Ibid.

11. These same criticisms are repeated in a further article which Professor Petter co-authored with Professor Allan C. Hutchinson, "Private Rights/Public Wrongs: The Liberal Lie of the Charter" (1988) 38 U.T.L.J. 278.

12. L.M.G. Clark, "Sexual Equality and the Problem of an Adequate Moral Theory: The Poverty of Liberalism" in Resources for Feminist Research, Special Publication 5 (Toronto; O.I.S.E. University of Toronto, 1979), "Liberalism and Pomography", in Pornography and Censorship (Eds. D. Copp and S. Wendell), (Buffalo, N.Y.: Prometheus Books, 1983). 
democratic aspect of Canadian society on the Charter may result in making it a more effective tool in the creation of a more fully social-liberal democracy. It also seems to me that it is strategically important to ensure that when we approach questions of the meaning and interpretation of the Charter, we do so by firmly situating it within the context of our evolving social democracy in order to ensure that it gets that 'large and liberal' reading necessary to the growth of the 'living tree ${ }^{13}$ rather than reducing it to theoretical acid rain showering on a withering.root.

In terms of the specific criticisms advanced in support of accepting the Charter from the cynic's point of view, what must be asked is whether, and to what extent, they are necessary and irreducible aspects of liberalism, or, to state the converse of this thesis, must we necessarily give up liberalism altogether in order to achieve a society free of the social and economic inequalities we abhor? Frankly, I am of the view that liberalism has more flesh on its bones than the cynics would have us believe; that it contains within itself principles which give it the ability to transcend some of its more objectionable presuppositions and to find new and different contexts for valid principles whose past instantiations have not only outlived their usefulness but have become real impediments to both liberty and equality. My purpose in what follows is to consider these issues first in relation to liberal theory, then in relation to problems specific to women's equality, and finally to evaluate the extent to which the impact of the Charter to date gives us justification for being either optimistic or pessimistic about the likelihood that the Charter will or will not be useful in the eradication of sexual inequality.

\section{LIBERALISM AND THE LIVING TREE}

Let me state my thesis at the outset. I believe that the cynics rely on a "bare bones" conception of liberalism, what I propose to call a "minimalist" liberalism, in order to make their case. I believe, however, that there is also a " $m a x-$ imalist" liberal position which incorporates much that the minimalists want, but which they suggest does not come, and cannot come, from liberal theory. The "minimalist" version of liberalism is, in my view, really the "libertarian" position, which certainly has its roots in classical liberal theory, notably that of Locke, but lacks the development of liberal theory which took place in the 19th century largely through the work of John Stuart Mill. The United States has, on the whole, been dominated by, a libertarian version of liberal ideology, which is not surprising given the time at which the United States was founded as a nation.

Canada, on the other hand, came into being as a nation in the 19th century by which time the liberalism of the late 17 th and 18 th centuries had been considerably influenced and tempered by continental European political theory, notably the works of Marx, Engels and the French socialists. Thus, the "welfare state" aspect of Canada's underlying political philosophy can, I think, be fairly attributed to these influences on liberalism.

13. This phrase first occurred in the famous "Persons" case, Edwards v. Attorney-General of. Canada, [1930] A.C. 124, in which it was stated that the constitution was "a living tree capable of gmwth and expansion within its natural limits". It was then invoked again in the Supreme Court of Canada's first Charter case, Law Society of Upper Canada v. Skapinker, [1984] 9 D.L.R. 161 judgment of Estey J., in which the approach of the Supreme Court to Charter interpretation was first explicitly set out, urging a "large and liberal interpretation". 
Both Canada and the United States are, and characterize themselves as, liberal democracies, but Canada has always had more commitment than the United States to principles of social democracy, as is illustrated well enough by its much greater political tolerance, particularly of communist and socialist philosophies, and by such social programmes as universal health care. Thus, while I would not want to hold out that Canada exemplifies a "most maximalist" liberal state, it has certainly been characterized by a greater commitment to social welfare principles and policies than has the United States.

While I would agree with Petter that it is a presupposition of classical liberalism that the existing distribution of wealth and power, namely, a decidedly unequal distribution of these social goods, is the product of "private initiative" rather than state action, and that the common law rules governing rights of ownership in private property are "prepolitical norms" presupposed by liberal theory, I think it is considerably overstating the case to say that these are, in fact, presumptions underlying the Charter which categorically preclude them from Charter scrutiny. To say this is to prejudge the issue and to legislate the outcome should such issues arise for adjudication. Such outcomes would certainly be consistent with classical liberalism, but are equally certainly not necessitated by it. I believe that at least part of what Canada's greater commitment to social welfare policies indicates is that Canada does not have nearly so entrenched a view, as does the United States, of the origins of unequal property distributions. This is to say that Canadians do not, on the whole, accept it as nearly so much an unchallengeable universal truth, as do Americans, that those who have more necessarily deserve it, and should keep it in perpetuity, because the rich exemplify the great Lockean virtues of rationality or industry or both in greater measure than others who lack such resources. While they may fail adequately to perceive the extent to which state action upholds these unequal distributions, I do not think that they attribute this to fundamental "natural" differences between men, such that some men are rightfully richer because they are naturally "better" in some respect than others are. It is precisely because Canadians have not accepted the view that some men are inherently better than others and therefore deserve more, that they have accepted, at least to a greater extent than Americans, that they have a responsibility to their fellow men to ensure such things as access to health care regardless of social position.

Thus, there already exist in Canada at least some "positive" rights to important social goods which the vast majority of Canadians do not see as being inconsistent with the principles of a liberal democracy. And there is therefore no good reason for saying that all the rights guaranteed under the Charter must necessarily be interpreted as negative rights. Indeed, a number of positive rights have already been developed under the Charter, as for example, the right to call a lawyer at the first reasonable opportunity, and to do so in private, as an incident to the exercise of rights guaranteed under s.10(b) of the Charter. It is certainly true that classical liberalism's strong suit is negative liberty, but that is not to say that liberal theory cannot encompass positive rights or that every right guaranteed by the Charter has to be interpreted negatively to be consistent with its liberal heritage. John Stuart Mill was a strong proponent of positive rights in many areas, most notably, and significantly for his time, with respect to education: ${ }^{14}$

14. J.S. Mill, On Liberty, ed. by C.V. Shields, (Indianapolis: The Library of Liberal Arts Publication ITT Bobbs-Merrill Educational Publishing Co., 1956 [originally published, 1859]), c.V. 
Is it not almost a self-evident axiom, that the State should require and compel the education, up to a certain standard, of every human being who is bom its citizen?

The history of Canadian human rights legislation also provides ample evidence of the ability of a modern liberal democracy to see that the ends which its legislative objectives seek to achieve can only be fulfilled by the granting of positive entitlements, as, for example, in Action Travail des Femmes v. C.N.R. ${ }^{15}$

With regard to the specific issue of equality rights, it has to be admitted that equality has been problematic within the liberal tradition and I am already on record as providing a critique of its weaknesses in this area. ${ }^{16}$ On the whole, equality has taken a back seat to liberty, which is unquestionably the central and core value of liberalism. Within classical liberal theory, equality was a value only as a purely formal concept, relating to issues of procedural fairness, and is virtually synonymous with, and exhausted by, the concept of "due process"'. Liberalism has not been centrally concerned with the promotion of substantive equality as even a long term social objective. It has always countenanced the existence of inequalities in the distribution of social goods and has thought it enough simply to ensure "equal opportunity' to pursue one's chosen goals.

Lockean liberalism was indeed centrally concerned to protect, entrench, and justify existing inequality in the ownership of property. Locke argued that inequality in the distribution of wealth occurred because of natural and moral differences between men. Those possessed of greater rationality and industry got more and should, for the same reasons, keep it. Locke was certainly not one to admit that differences in natural ability were socially determined or that any such differences in any way detracted from the equality of men in the state of nature. His was the paradigm equal-opportunity argument: all men are formally equal in the unregulated state of nature. Those who saw the advantage of hard work and acted on it got more and deserved it. Of course, Locke's political world was peopled only with males; women come into the picture only along with other household baggage.

But with Mill came an implicit recognition that inequality in the distribution of wealth was not to be explained away merely on the basis of a "natural" mental and moral superiority of one person over another. Mill explicitly recognized that the state was justified in instituting policies designed to promote greater equality, particularly where inequality, as in the case of women, resulted from unjustified discrimination. Thus, Mill introduced the concept of substantive equality as a principle of rectification, at least in cases of unjustified discrimination. It is also of note that Mill recognized that inequality can be a characteristic of a class or group as well as of an individual. Thus, liberal theory does contain principles which allow for a wider rather than a narrower, a substantive, rather than a merely formal,

15. Action Travail des Femmes v. C.N.R. Co., [1987] I S.C.R. 1114. This case arose under the Canadian Human Rights Act, S.C. 1976-77, c.33. It was not a complaint of a single individual or even a number of individuals, but of systemic discrimination practiced against an identifiable group. It was a challenge to the authority of a Human Rights Tribunal appointed under s.39 of the Act to impose upon an employer a program tailored specifically to address systemic discrimination in the hiring and promotion of women. The Court held that the Tribunal did have the power to do so under s.41(2)(a) of the Act. The program included among many other provisions that the Canadian National Railway Co. hire at least one woman for every four non-traditional positions filled in the future and that this policy be complied with over each quarterly period until $13 \%$ of non-traditional positions were filled by women.

16. Clark, Lorenne M.G., "Liberty, Equality, Fraternity - and Sorority," in Anne Bayefsky, ed., Legal Theory Meets Legal Practice (Edmonton, Alberta: Academic Printing and Publishing, 1988) at 261-81. 
interpretation of equality, and recognizes that the promotion of greater substantive equality is a legitimate social goal.

\section{WOMEN'S INEQUALITY: "RELIC OF THE PAST"}

Particularly within the present context, I can think of no better way to begin an explication of the unique problems posed by the unequal and inferior socioeconomic status of women than by starting with a quotation from John Stuart Mill's essay, "The Subjection of Women", first published in 1869:17

". . . the principle which regulates the existing social relations between the two sexes - the legal subordination of one sex to the other - is wrong in itself, and now one of the chief hindrances to human improvement; and that it ought to be replaced by a principle of perfect equality, admitting no power or privilege on the one side, nor disability on the other. ${ }^{18}$ [emphasis added]

Fundamental to an understanding of the structural significance of women's inequality is appreciation of the fact, so clearly evident to Mill, that itstems from legally imposed and enforced subordination to men. Mill is also clear that what he terms "the social subordination of women", 19 "the authority of men over women", 20 is:simply a remaining. vestige of might makes right: ${ }^{21}$

... the inequality of rights between men and women has no other source than the law of the strongest.

Men in non-rule-governed states of nature simply appropriated women and then, with the development of law, made de facto relations of domination and subordination de jure principles of allegedly civilized life. As he states it:22

It arose simply from the fact that from the very earliest twilight of human society, every woman (owing to the value attached to her by men, combined with her inferiority in muscular strength) was found in a state of bondage to some man. Laws and systems of polity always begin by recognising the relations they find already existing between individuals. They convert what was a mere physical fact into a legal right, give it the sanction of society, and principally aim at the substitution of public and organized means of asserting and protecting these rights. . . . Those wha had already been compelled to obedience become in this manner legally bound to it.

The conclusion he draws from this is as follows: ${ }^{23}$

The preceding considerations are amply sufficient to show that custom, however universal it may be, affords in this case no presumption, and ought not to create any prejudice, in favour of the arrangements which place women in social and political subjection to men. But I may go further, and maintain that the course of history, and the tendencies of progressive human society, afford not only no,presumption in favour of this system of inequality of rights, but a strong one against it. . . . this relic of the past is discordant with the future, and must necessarily disappear.

As is abundantly clear from this, Mill was as fully cognizant as I am of the fact that all political, social, and legal theory has presupposed the natural superiority of men over women and a particular set of sociakarrangements respecting maleand female sexual and reproductive relations which was assumed to be "natural". He is certainly not exempting his own liberal democracy from this criticism. It.is clear that while these mistaken presuppositions are part of liberal theory, they are by no means

17. J.S. Mill, "The Subjection of Women", in Essays on Sex Equality (Alice S. Rossi), (Chicago and London: University of Chicago Press, 1970) at 123ff.

18. Ibid. at 125.

19. Bbid. at 146.

20. Ibid. at 129 .

21. Ibid. at 131 .

22. Ibid..at 129-30.

23. Ibid.at.142. 
unique to it. More importantly, Mill did not believe they were necessary to it either. Thus, in so far as these presuppositions have been legally articulated and enforced to create the most fundamental inequality in the distribution of property characteristic of this and other societies, namely that between women and men, it would appear to be the case that Mill would have seen this as necessarily coming under the scrutiny of an enlightened State fundamentally committed to guaranteeing the liberty of all of its subjects.

Mill clearly recognized sexual inequality as a systemic problem rooted in blatant discrimination against women: discrimination legitimized and enforced by the State, rooted not in nature but in brute force, and secured by compelled compliance. To suggest that he regarded this as beyond State control is unsupportable on the basis of his express views on the matter. Mill's views are as candid as one could expect from the most radical contemporary feminist on the injustice of this and on the need for its elimination. He is as clear as we are about the central problem, namely, the allegedly "natural" authority men continue to exercise over women and the double bind in which this places women. The State continues to legitimize and reinforce that exercise of unjust authority of men over women. It places upon women a double task: that of overcoming the domination of men in the private sphere of sexual and reproductive relations while simultaneously fighting for reform and renovation of a public sphere which condones and supports the very structure of private sphere relations from which they are attempting to escape.

Nor is Mill naive. He knows the masters are not easy to convince. He says: ${ }^{24}$

Some will object, that a comparison cannot fairly be made between the government of the male sex and the forms of unjust power which $l$ have adduced in illustration of it, since these are arbitrary, and the effect of mere usurpation, while it on the contrary is natural. But was there ever any domination which did not appear natural to those who possessed in? [emphasis added]

Thus, the primary job of government in relation to the elimination of sexual inequality is to disavow any justification for the continuing exercise of an unjustified authority of men over women in so-called private sphere relations; a striking down of all legal supports for legitimation of male authority over women in relation to sex and reproduction; and the provision of positive rights to ensure not only women's equal opportunities of access to the public sphere, but their substantive equality in both the public and the private sphere through the mechanism of enforced employment equity programmes. These programmes must include equal pay for work of equal value; the provision of universal, state supported, full-time day care programmes; income support programmes designed to permit women to leave abusive family relations without being forced to exist at or below the poverty line; and pension programmes designed to provide adequate income levels in old age regardless of paid labour-force participation. ${ }^{25}$ The domination of men, and the correlative subordination of women, will only cease when women are no longer socially (male) defined in terms of their sexual and reproduotive functions, when their labour force participation is unrestricted and non-stratified, and when the social and economic costs of raising children are State supported.

The virtue of liberalism in these respects is that it articulates a single set of principles regarding what shall constitute acceptable standards of behaviour between

24. Bbid. at 137.

25. See for example the discussion of the possible unconstitutionality of the Canada Pension Plan and the Pension Benefits Standards Act in S.W. Rowley, "Women, Pensions, and Equality", in Charterwatch: Reflections on Equality, ed. by Boyle, MacKay, McBride, and Yogis, (Toronto: Carswell, 1986) at 283. 
individuals, namely, that everyone shall be permitted to do whatever does not cause harm to others, where one of the "harms" to be avoided is interference with the exercise of like rights by others. Its weakness has been that it has failed to apply these principles in the "private" sphere, the sphere of sexual and reproductive relations between the sexes, for precisely the reasons articulated by Mill. But it does not have to be, and indeed on its own principles should not be, committed to maintaining that distinction because that is precisely the mechanism by which the State has legitimized and supported the unjust exercise of male authority over women.

It certainly follows from this that the State has not been a friend to women. But it does not have to remain an enemy. The measure of its transformation will be the extent to which it recognizes and addresses the specific problems of male domination and female subordination and the mechanisms by which that unequal status is kept intact. With these perspectives in mind, I wish now to turn to a consideration of the impact the Charter has had in relation to these issues and the ways in which it might be utilized in the future to obtain these objectives.

\section{THE CHARTER: TOWARDS A PRINCIPLE OF "PERFECT EQUALITY"}

In terms of the specific faults Petter has pointed to as likely to prevent the Charter from doing very much to cure fundamental social inequalities, enough has been said regarding the theoretical basis for assuming that the rights enumerated must be, or are most likely to be, interpreted negatively, except to point to the existence of s.15(2) which clearly envisages the possibility of court-imposed affirmative action programmes. It is simply too early to tell whether this provision will be used merely to immunize already existing affirmative action programmes which create positive entitlements from attack under s.15(1). However, there appears to be considerable academic support for at least guarded optimism in this regard. ${ }^{26}$

Enough has also been said about the context in which these rights are imbedded. So far as identifying the "main enemy" of women's equality, that is an easy task: men, and the State which has upheld the continued exercise of male authority over women, creating women as a subordinate and certainly a disadvantaged class. This is not to deny that the private-sector economy has certainly not been a friend to women either, but they have acted as they have because the State has neither forbidden them from discriminating against women nor obliged them to create positive entitlements to counter the effects of that discrimination, although there are some signs that this may be changing with such things as the Employment Equity Act. $^{27}$

Also, I think it clear from our consideration of Mill that he does not think that the structural roots of women's inequality are either natural or immune from governmental scrutiny. And I certainly think that his analysis of women's equality provides forceful ammunition in arguing that women are unquestionably a "disadvantaged group", should the court require convincing on that issue.

With respect to Petter's concerns about the judicial system in these respects, one does not have to look far in the history of women's struggle for equality to appreciate

26. See D. Greschner, "Affirmative Action and the Charter of Rights and Freedoms", 16 Canadian Women's Studies at 4 and 34-36.

27. Employment Equity Act, S.C. 1976-77, c.33, and subsequent amendments. 
that women have had about equal assistance from the democratic and the judicial arenas. It was, after all, a decision of the Privy Council which gave Canadian women their personhood, not the "democratic arena", and I use the term advisedly. From the perspective of women, the democratic arena is no more democratic than the judiciary so far as its composition is concerned. The "democratic arena" was not even prepared to give us a protected right to equality without a fight. If the legislatures want to demonstrate their bona fides in relation to the issue of women's equality, why don't they mandate an equal composition of men and women both in the legislatures and on the bench? The so-called "democratic" arena is certainly not noted for any special partiality toward women. It wouldn't even give us a guarantee of even a few seats on the bench of the Supreme Court of Canada, much less $50 \%$ of them. This argument rings decidedly hollow in the ears of Canadian women.

In the areas of key concern to women, and those already identified as key to their subordinate position, namely rights over our own bodies, it has been the judiciary and not the elected members of the democratic arena that has come to our assistance. The most significant gain for women since the coming into effect of the Charter was the decision of the Supreme Court of Canada in the Morgentaler case.$^{28}$ The elected legislature had flatly refused to give women the right to control over their own reproductive activity despite persistent lobbying for at least twenty years. Not only did the Supreme Court of Canada do what parliament refused to do, but it did it for the right reasons and under the only section of the Charter where it really belonged. Control over women's sexual and reproductive functions has been, and is, the primary mode of male domination of women. The issue is centrally a s.7 issue. In finding that "state interference with bodily integrity and serious stateimposed psychological stress . . . constitutes a breach of security of the person", as per the judgment of Dickson C.J., and concurred in by Lamer J., and that limiting "the pregnant woman's access to abortion violates her right to life, liberty and security of the person within the meaning of s.7', as per the judgment of Wilson J., the court did exactly what it should have done in terms of our analysis of how the State should now act to strike down legislative supports for the domination of women by men. Though mindful as I am of the results in Dolphin Delivery ${ }_{, 29} \mathrm{I}$ am not meaning to suggest that the judiciary either is indistinguishable from, or identical with, the State. The State did not do this by repealing s.251 of the Criminal Code, but the Court did, which simply underscores the point that there is no reason to assume that the course of women's equality will be better served by the allegedly democratic arena than by the judicial arena.

I do agree with Petter that restricting the application of the Charter to the public sector does fail to acknowledge the fact that significant inequality occurs as a result of private sphere economic activity and that this is a regrettable feature of its liberal heritage. I therefore agree wholeheartedly with Professors Petter and Hutchinson's criticism of Dolphin Delivery and with their thesis that "constitutional norms ought to apply to and inform all facets of Canadian life; Charter justice

28. Morgenzaler v. The Queen, [1988] 1 S.C.R. 30.

29. R.W.D.S.U. v. Dolphin Delivery, [1986] 2 S.C.R. 572. In this decision the Court held that a Court Order granting an injunction is not "governmental action", that in applying the law the Court does not act as a branch of government but as "neutral arbiters". 
must be available in both the private and the public realms." 30 Women are doubly disadvantaged because of the distinction between allegedly public and private economic realms and the relegation of reproductive relations to a private sphere immune from public scrutiny.

As I have already pointed out, one of the greatest failings of liberalism has been its failure to see that its own principles should apply across the board. In failing to have them apply to forms of economic activity, and to interpersonal sexual and reproductive relations, liberalism legitimizes the perpetuation of many forms of unjustified systemic discrimination and undermines its ability to achieve the equal liberty of subjects to which it is centrally committed.

Perhaps the greatest impediment to liberalism's ability to realize its potential to articulate a framework for a fully developed social democracy lies in the danger that the democratic and the judicial arenas may, between them, jointly fail to implement the Charter vision of equal liberty. This is well illustrated by Wade MacLauchlan's analysis of recent changes in the Criminal Code provisions respecting soliciting. He argued persuasively in his analysis of $R$. v. Tremayne $e^{31}$ and $R$. v. McLean, ${ }^{32}$ that in:enacting s.195.1 of the Criminal Code as a response to criticisms of the previously existing provisions pertaining to prostitution, the federal government not merely failed to alleviate the condition of "one of the most oppressed classes in our society" 33 but can fairly be said to have "deliberately chosen to worsen the situation of prostitutes." 34 "When this section was subjected to Charter challenge; however, the B.C. Supreme Court failed "to do anything about a law where.Parliament has deliberately opted to deal with the complex problem of prostitution . . . by sweeping prostitutes themselves further into a spiral of criminality, violence, vulnerability to control by others and continued societal condemnation." 35 As he states it, the causes of this are as follows: ${ }^{36}$

Instead of dealing: with this matter squarely as a problem of equality or fundamental justice, the judgments focus uponlibertarian concerns regarding freedom of expression, freedom of association and vagueness or overbreadth.

He then goes on to develop a potentially successful constitutional challenge to the soliciting provision on the following basis: ${ }^{37}$

... the argument ought to be that sections 7 and 15 of the Charter informed by other provisions, particularly s.28, combine to protect against legislatively based losses of dignity, particularly where the loss of dignity involves a deprivation of liberty or security of the person, and particularly where members of the target group in significant measure share other characteristics which are constitutionally suspect on equality grounds, such as sex, sexual preference and social condition. In short, Parliament cannot deliberately or recklessly worsen the situation of a group which is already vulnerable.

30. Supra, note 11 at:288.

31. (May 6, 1986), Vàncouver CC860492 \& CC860563, rev'g (10 April, 1986), Vancouver 68098C (Prov. Ct.), Lemiski, J. and (17 March 1986), Vancouver 69038C (Prov. Ct.), Libby J.

32. MacLauchlan, H.W., "Of Fundamental Justice, Equality and Society's Outcasts: A Comment on $\boldsymbol{R}$. v. Tremayne and R: v. McLean" (1986) 32 McGill L. J. 213.

33. Ibid. at 223.

34. Ibid.

35. Ibid. at 214-15.

36. Ibid.

37. Ibid. at 225-226.' 
If the democratic and judicial arenas fail to function as effective checks on one another, to ensure against a narrow and rigid interpretation of the Charter across a broad range of significant issues, then the Charter will fail to achieve the realization of a liberal-social democracy in Canada. However, the fault for this will then lie with a lack of will, and with the unrepresentativeness of both of those arenas, and not with the Charter or with liberalism. I believe that these considerations illustrate that liberalism is quite capable of supporting that large and liberal reading which is necessary to enable the Charter to fulfill its mandate within the context of Canada's evolving social democracy and that the Charter can, and will, be significant in ridding us of the dusty relics of the past. 